\title{
Typology of The Coastal Countryside in Supporting Development of North Coast Region in West Java
}

\author{
Apriadi Budi Raharja ${ }^{1}$, Supratognyo Aji ${ }^{2}$, Deden Syarifudin ${ }^{3}$
}

Received: 30 ${ }^{\text {th }}$ March 2020

Disetujui: $10^{\text {th }}$ July 2020

\begin{abstract}
The pressure from rapid development causes condition of resources and living quality to be less than ideal for future development. The economic characteristics of northern coast regions of West Java commonly deals with fish farm, ground fish catch, industrial area, ship repair, and tourist. This study aimed to reveal the typology of rural area, north coast of West Java province. The analysis used was multivariate to identify a group of objects that have the semblance of a characteristic parameter based on natural resources and human resources. Research locus on six counties that consist of 124 identified villages is a village along northern coast of West Java. Based on analysis of rural typology, four of the rural types were found, namely; typology 1 (comprised 55 villages); typology 2 (48 villages); typology 3 (10 villages); typology 4 (11 villages). Coastal villages of Pantura have a fast transition, however the transition occurred tends to shape village's characteristic and still unable to improve service quality and quality of life of rural communities.
\end{abstract}

Keyword: village, typology, communities

\section{INTRODUCTION}

The government's efforts to reduce inequality are quite massive; from the development of regional autonomy laws, village laws, village funds, agrarian reform policies, increasing productivity of the primary sectors (agriculture, fisheries), housing provision, retail shop arrangements, HR development, implementation of progressive taxes, labor intensive programs, to other sectorial programs. These efforts was reflected in the value of the Gini Ratio in March 2018 in rural areas of 0.324 while in higher urban areas it was recorded at 0.401 (BPS, 2018). Encouraging rural development to realize rural life is certainly not easy. As defined by Robet Chambers and Gordon Conway in (Sajid et al., 2017) rural life (rural livelihood) as capabilities, assets and activities that are synergistic for living facilities. Rural actors who are able to develop and adapt can overcome challenges by creating opportunities. Furthermore (UNDP, 2017) sustainable rural livelihood, namely villages can understand certain situations, be creative in responding challenges, and be able to understand the availability of resources that affect human capital, social capital, natural capital, physical capital, and financial capital.

West Java Province which has 5,321 villages, of which has $25.5 \%$ as underdeveloped villages, and $1.1 \%$ as very disadvantaged villages (Hamidi et al., 2015). Most of the rural conditions are in coastal areas. The northern coastal area of West Java stretches along +354.2 kilometers from Bekasi Regency, Karawang Regency, Subang Regency, Indramayu Regency, Cirebon City to Cirebon Regency. Based on the physical environment, West Java, Pantura, has the characteristics of sloping and protected beaches, which causes the

\footnotetext{
${ }^{1,2,3}$ Urban and Regional Planning Department, Pasundan University
} 
progress of development in the northern coastal region to be relatively fast. Judging from the territorial connectivity, Bekasi Regency and Karawang Regency are included in the Metropolitan section of Bodebekkarpur as the DKI Jakarta metropolitan twin (Aji \& Rismana, 2017), of course this gives more specific characteristics of socio-economic activities. However, in general the economic characteristics of West Java northern coast are identical to fish farming development centers, fishing catch landings, industrial estate development, ship repair services, and tourism services. High development pressure causes conditions that are not ideal for rural development in the future. Environmental impacts such as abrasion, sedimentation, tidal flooding, and eutrophication which causes crop failure in fish farming such as those experienced by farmers in Karawang District and Cirebon District are common problems faced by the north coast communities of West Java.

The development of coastal villages is expected to be of course development that does not only focus on reducing inequality, but rather on development that is oriented towards increasing the capacity of rural communities by increasing the productivity of their potential resources, so they can independently surpass critical situations [3]. This opinion is reinforced by (Prabatmodjo, 2006) the technocratic approach of sustainable development; by controlling the population limiting excessive ways of life, and improving technology, it can encourage development that is unfair (exclusive) to increase underdevelopment for undeveloped regions. For this reason, the approach to the development needs of coastal rural areas that are adaptive to the conditions of the coastal region's resources and conditions of environmental change are needed to determine the route of the development approach, ultimately realizing sustainable coastal rural life. Character diversity of diverse rural areas (Hedlund, 2016) needs to be addressed with more specific treatment to encourage its development.

Based on that description, this study aims to reveal the typology of northern coast rural area of West Java Province. The North Coast Coastal Area of West Java is the most active economic route on Java even in national context, but still has challenges in terms of rural areas that are lagging behind and have significant number of poor people. It needs to be realized that coastal areas have a distinctive diversity in each region, so this research identifies the typology of coastal rural areas that are formed and ultimately expected to become information for all parties in an effort to improve the quality of life for the north coast communities of West Java.

The helplessness of rural areas to compete causes the poverty rate to be higher and also the environmental degradation to be wider, the relationship is raised by Karshenas In [6]. So according to (Widodo, 2011), coastal communities generally depend their lives on the use of marine and coastal resources that require large investments and greatly depend on season. Types of livelihood are as fisheries (traditional fishermen, modern fishermen), fish farming, sand miners, sea transportation, traders, manual laborers, laborers (Anwar, 2013); (Fatmasari, 2016). The diversity of livelihoods in a coastal area at a given time is also strongly driven by changes in socio-economic innovation (Liu \& Liu, 2016) and also the technology used (Satria, 2015). Data on lagging and very underdeveloped villages in coastal areas are multidimensional problems related to social, economic, cultural and other aspects, Sumodiningrat In (Natalia \& Alie, 2014).

\section{METHOD}

\section{Case study research}

Connection between poverty and environmental degradation is very close as stated by Karshenas In (Prabatmodjo, 2006). Thus, from statistics in 2018, West Java Province's Gini Ratio always oscillates, but the percentage of poor people in the last 10 years in 
districts / cities that is located on the north coast of West Java only Bekasi regency that have a number of poor people below the average of West Java Province.

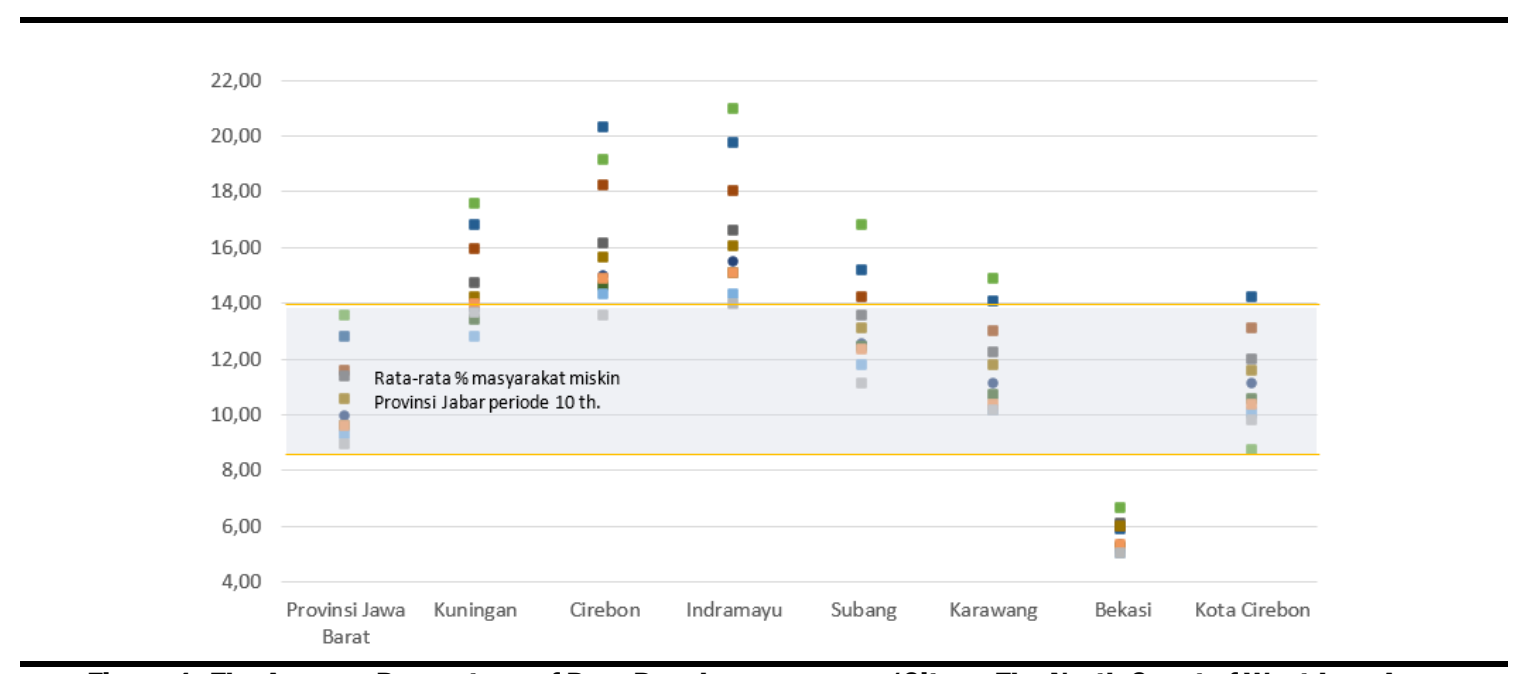

Figure 1. The Average Percentage of Poor People per regency/City on The North Coast of West Java Area

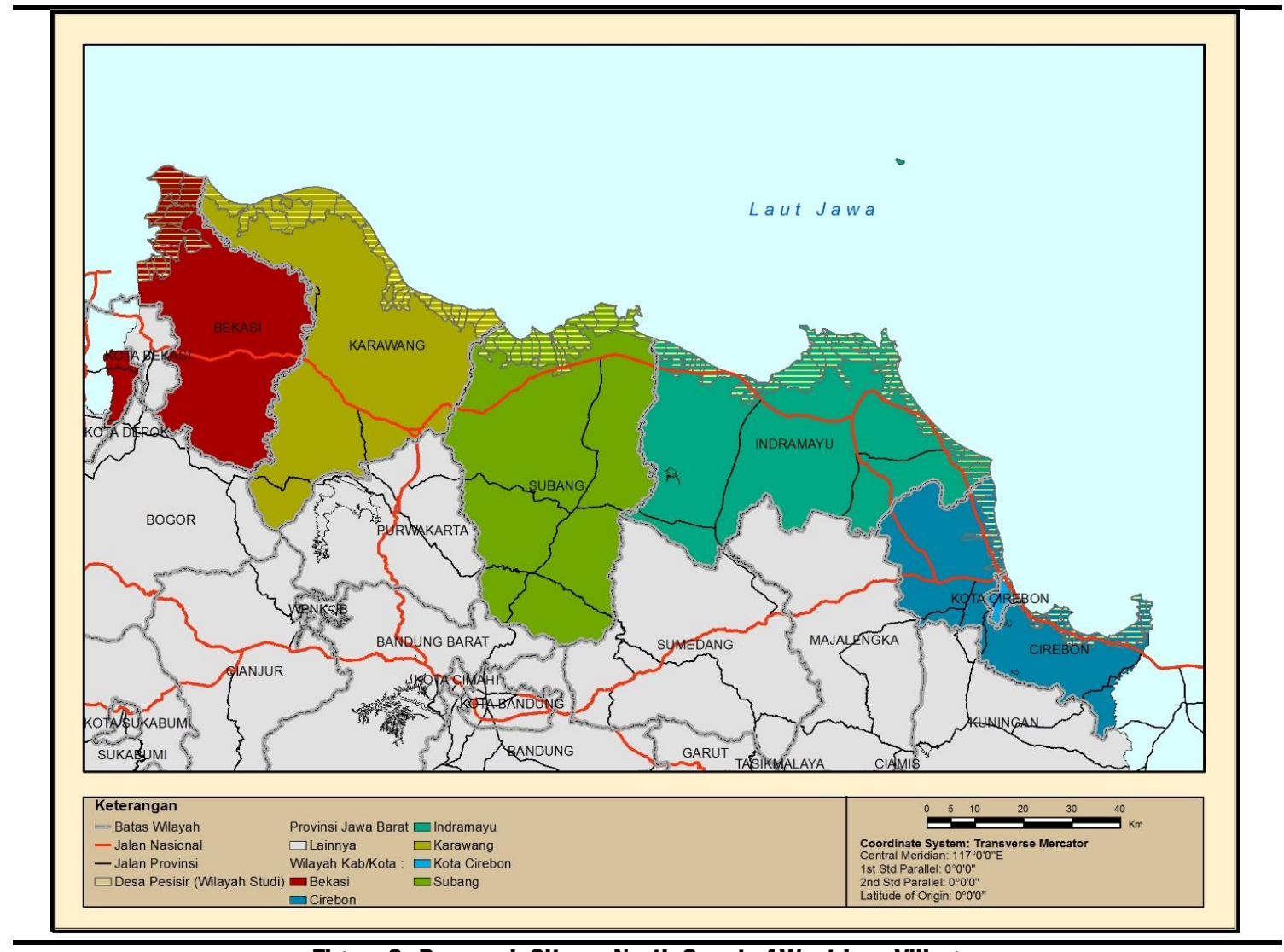

Figure 2. Research Site on North Coast of West Java Villages

Furthermore (Prabatmodjo, 2006) added, poverty in its various manifestations was caused by internal factors (limited natural resources, facilities and infrastructure, capital, knowledge and technology, and cultural constraints) and rural external factors (government strategic policies, global effects). The characteristics of coastal areas that are very diverse both from the condition of natural resources, human quality and capacity, economic level, physical environment and political policies provide their own challenges, so they cannot be 
unified in providing solutions to the problems they face (Satria, 2015). Based on this, the study was conducted in six regency / city regions consisting of 124 villages identified as village areas along the northern coast of West Java.

\section{Method of Analysis}

The study was conducted with quantitative descriptive methods based on 27 data which are divided into five dimensions of rural environmental assets. The approach to sustainable livelihoods approach is one of methods to improve understanding of life quality with a multidimensional approach in the context of rural areas (Kamaruddin \& Samsudin, 2014).

Secondary data collection aimed to find information sourced from literature studies and related institutions regarding the category of assessment of the northern coastal areas of West Java, including related institutional visits. Whereas primary data collection is done through site visits related to the actual conditions of coastal village developments.

The framework of this research began with rural coastal problems and is based on theory and literature. Empirically, it is illustrated through data on the diversity of rural areas in the north coast of West Java, then analyzed using hierarchical cluster analysis methods to produce rural typologies. The diversity of data on coastal rural areas is based on natural resource parameters (covering the area of land constructed, area of agricultural land, cover of mangrove ecosystems, cover of seagrass ecosystems, and cover of coral reef ecosystems), and human resources (including population, working in the agricultural sector, and non-sector work) -agriculture). In the end, the rural typology was assessed based on the Z-Score and presented on the radar graph.

Table 1. Assessment Category of Coastal Villages Lead to Framework of Sustainable Livelihoods Approach

\begin{tabular}{|c|c|c|c|}
\hline Dimension & Factor & Unit & Data Source \\
\hline \multirow[t]{6}{*}{ Natural Resource } & Village area & $\mathrm{Km}^{2}$ & BPS, 2018 \\
\hline & Land area built & $\%$ & RBI, BIG \\
\hline & Agricultural land area & $\%$ & RBI, BIG \\
\hline & Extent of mangrove ecosystem & $\mathrm{Km}^{2}$ & RZWP3K Jabar \\
\hline & Seagrass ecosystem cover & $\mathrm{Km}^{2}$ & RZWP3K Jabar \\
\hline & Coral ecosystem cover & $\mathrm{Km}^{2}$ & RZWP3K Jabar \\
\hline \multirow[t]{7}{*}{ Human Resource } & Sex ratio & $\%$ & BPS, 2018 \\
\hline & Productive age & people & BPS, 2018 \\
\hline & Agriculture sector & $\%$ & BPS, 2018 \\
\hline & Non-agriculture sector & $\%$ & BPS, 2018 \\
\hline & Population total & people $(000)$ & BPS, 2018 \\
\hline & Population density & people $/ \mathrm{Km}^{2}$ & BPS, 2018 \\
\hline & Income level & Rp/year & BPS, 2018 \\
\hline \multirow[t]{2}{*}{ Financial } & Capital loan access & Unit & KemKop\&UKM \\
\hline & Land value zone & $\mathrm{Rp} / \mathrm{m}^{2}$ & $\mathrm{ATR} / \mathrm{BPN}$ \\
\hline \multirow{10}{*}{$\begin{array}{l}\text { Physical } \\
\text { Environment }\end{array}$} & Sanitation access & $\%$ & CK, PUPR \\
\hline & Clean water access & $\%$ & CK, PUPR \\
\hline & Distance to water source & $\mathrm{Km}$ & CK, PUPR \\
\hline & Education access & Unit & BPS, 2018 \\
\hline & Health access & Unit & BPS, 2018 \\
\hline & Road accessibility & $\mathrm{Km} / \mathrm{Km}^{2}$ & BPS, 2018 \\
\hline & Road length & $\mathrm{Km}$ & RBI, BIG \\
\hline & $\begin{array}{l}\text { Production supporting } \\
\text { infrastructure }\end{array}$ & Unit & BPS, 2018 \\
\hline & Electrification access & $\%$ & BPS, 2018 \\
\hline & Telecommunication / internet & $\%$ area & Provider \\
\hline
\end{tabular}




\begin{tabular}{cllc}
\hline \multicolumn{1}{c}{ Dimension } & \multicolumn{1}{c}{ Factor } & \multicolumn{1}{c}{ Unit } & Data Source \\
\hline \multirow{3}{*}{ Social/Politic } & wireless access & & Total \\
& $\begin{array}{l}\text { Business groups } \\
\text { Distance to the district activity } \\
\\
\text { center }\end{array}$ & $\mathrm{Km}$ & $\begin{array}{c}\text { Jabar } \\
\text { RBI, BIG }\end{array}$ \\
\hline source : adapted from (UNDP, 2017); (Liu \& Liu, 2016); (Serrat, 2017); (Scoones, 1998); &
\end{tabular}

\section{DISCUSSION AND SUGGESTION}

The northern coast of West Java Province is dominated by land and water areas that are productive and have sufficient carry capacity to be developed. High activity development has a group tendency compared to low activities development. This can be seen from the high interest of the community to live in the area. The distribution of the activity center of villages on the north coast of West Java tends to be clustered in the city administrative area compared to the district administrative area with an average distance of $3.7 \mathrm{~km}$ to the center of the sub-district. Based on the results of identification, there are differences among rural areas that are presented through the Cartesian quadrant graph by raising several development issues including ease access issues, resource potential issues, and infrastructure issues.

Ease Access Issues, accessibility in rural areas is a major factor in encouraging the distribution of agricultural, fisheries and other economic activities. Based on the road accessibility index $(\mathrm{km} / \mathrm{km} 2)$ the highest ratio is 12.86 in Sukamaju Village, Kecasari (S12) Subang Regency. Based on the type of its status, the road network with trail status dominates the research site, it is thought to be the access of production networks from plantations or ponds to the collectors which is usually located at the center of settlements. This is rarely found in areas identified as urban areas, such as in Gunungjati Sub-District, Cirebon City, which are identical in economic activities to rice fields and trade services.

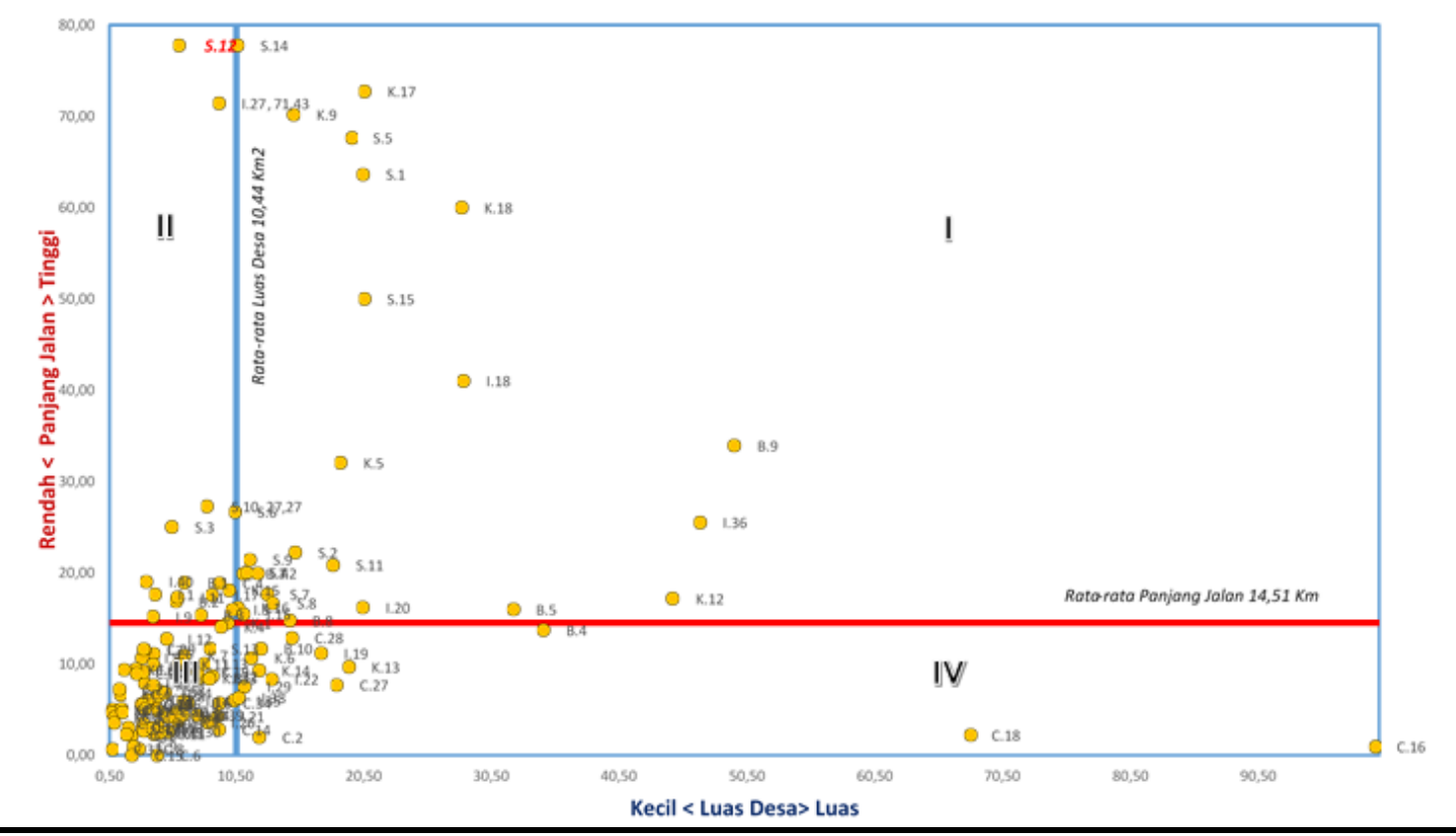

Figure 3. Quadrant of Ease Access Issues

Infrastructure issues, especially roads, show that high built up land is identical to the availability of high road networks; as in Sukamaju Village, Kecasari (S12), Cemara Village, Cantigi (I36) and Sedari Village in Cibuaya District (K12), Figure. 4. Potential Resource 
Issues, Characteristics of potential human resources in coastal villages based on the number of Dependency Ratios is proportional to population, as depicted in Segaramakmur Village (B1) included in the region with the highest proportion of population compared to other villages, while the smallest productive age is in Mayangan Village (S3). However, the ratio of productive age is in Bandengan Village (C32). The high productivity age ratio indicates that the economy is growing in a village. There are 48 villages or $38.7 \%$ are included as villages that have a productive age ratio above the average coastal villages. Figure. 5.

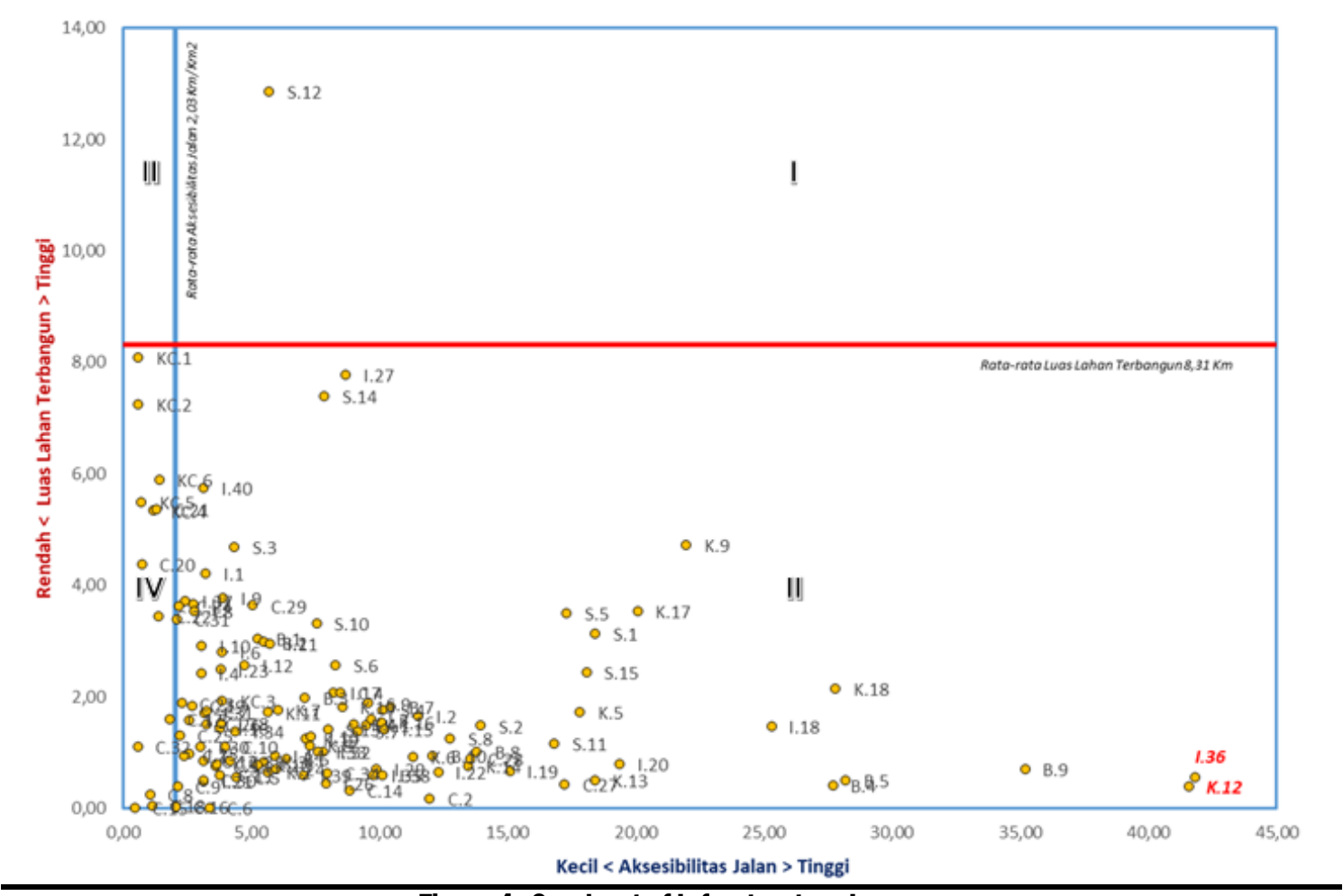

Figure 4. Quadrant of Infrastructure Issues

Coastal and marine biodiversity in the form of mangrove ecosystems, coral reefs and sea grass beds can be seen from the existence of West Java coastal villages. Based on land cover data, there are villages that have mangrove areas $>3 \mathrm{Km} 2$ namely Pantai Bahagia Village Muara Gembong sub district, Tambaksari Village Tirtajaya Sub district, Pangarengan Village and Tegalurung Village, Legonkulon Sub district, and Patimban Village Pusakanegara sub district. With the huge mangrove area, it created a significant economic potential that dominates the aquaculture sector with the commodity of milkfish, shrimp and crabs. Whereas villages that do not have mangrove ecosystems are Majakerta Village, Balongan Subdistrict, Singajaya Village, Indramayu District, Eretan Wetan Village, Kandanghaur Village, Kesepuhan Village, Lemahwungkuk Subdistrict, Panjunan Village, Lemahwungkuk Village and Adidharma Village.

Based on the results of rural typologies from the parameters of natural resources and human resources owned by 124 villages, certain characteristic similarities, which can be separated from rural groups, can be generated. The rural typology formed by the similarity of characteristics possessed certainly has the ease of assessing the extent of sustainability conditions of the rural life in the North Coast of West Java. The aim of sustainable livelihood based on WCED (1987) In (Rugrq, 1991) is as the adequacy of resource capital to meet basic needs and to be able to manage and maintain productivity in the long run. 
Clearly, the existence of resources, activities, and access and infrastructure assets are expected to improve the quality of life of rural communities. Details on the number of clusters with the village members formed are determined to be four clusters which are also referred to as rural typologies. When referring to Redelift In (Prabatmodjo, 2006) who distinguished them into four types namely rural ecological function bearers, rural limited community carriers, rural production function bearers, and rural urban expansion carriers, the typology formed as follows, Table. 2 .

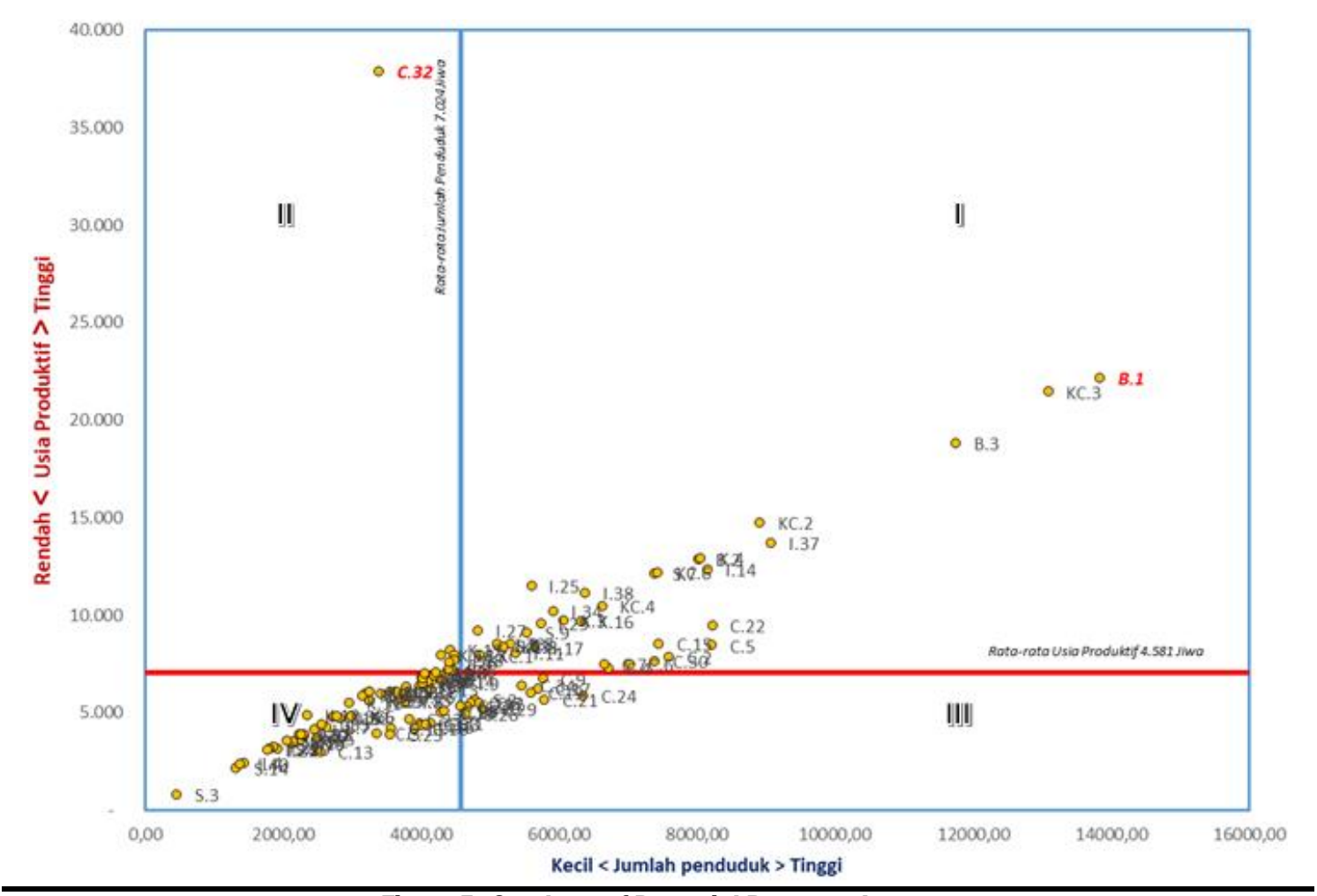

Figure 5. Quadrant of Potential Resource Issues

Table 2. North Coast of West Java Villages Typologies

\begin{tabular}{|c|c|c|c|c|c|c|c|}
\hline \multirow{2}{*}{$\begin{array}{c}\text { Village } \\
\text { Typology }\end{array}$} & \multicolumn{6}{|c|}{ Area } & \multirow{2}{*}{ Characteristics } \\
\hline & Bks & Krw & Sbg & Idr & Crb & Kcrb & \\
\hline $\begin{array}{l}\text { Typology 1; } \\
\text { Community } \\
\text { based }\end{array}$ & $\begin{array}{c}7 \\
\text { Village }\end{array}$ & $\begin{array}{c}8 \\
\text { Village }\end{array}$ & $\begin{array}{c}1 \\
\text { Village }\end{array}$ & $\begin{array}{c}21 \\
\text { Village }\end{array}$ & $\begin{array}{c}18 \\
\text { Village }\end{array}$ & - & $\begin{array}{l}\text { - Low ecosystem cover } \\
\text { - Low population } \\
\text { density } \\
\text { - High labor ratio. }\end{array}$ \\
\hline $\begin{array}{l}\text { Tipologi 2; } \\
\text { Production } \\
\text { Function }\end{array}$ & $\begin{array}{c}2 \\
\text { Village }\end{array}$ & $\begin{array}{c}10 \\
\text { Village }\end{array}$ & $\begin{array}{c}13 \\
\text { Village }\end{array}$ & $\begin{array}{c}12 \\
\text { Village }\end{array}$ & $\begin{array}{c}11 \\
\text { Village }\end{array}$ & - & $\begin{array}{l}\text { - Wide agricultural area. } \\
\text { - Low population } \\
\text { density. } \\
\text { - High farmer household } \\
\text { ratio. }\end{array}$ \\
\hline $\begin{array}{l}\text { Tipologi 3; } \\
\text { Coastal } \\
\text { ecology } \\
\text { Function }\end{array}$ & $\begin{array}{c}1 \\
\text { Village }\end{array}$ & $\begin{array}{c}1 \\
\text { Village }\end{array}$ & $\begin{array}{c}1 \\
\text { Village }\end{array}$ & $\begin{array}{c}7 \\
\text { Village }\end{array}$ & - & - & $\begin{array}{l}\text { - High coastal ecosystem } \\
\text { area cover. } \\
\text { - Quite high agricultural } \\
\text { area. } \\
\text { - Low population } \\
\text { density. }\end{array}$ \\
\hline $\begin{array}{l}\text { Tipologi } 4 \\
\text { City or City } \\
\text { Expansion } \\
\text { Tendency } \\
\end{array}$ & - & - & - & - & $\begin{array}{c}5 \\
\text { Village }\end{array}$ & $\begin{array}{c}6 \\
\text { Village }\end{array}$ & $\begin{array}{l}\text { - High developed area. } \\
\text { - High financial access. } \\
\text { - High population } \\
\text { density. }\end{array}$ \\
\hline
\end{tabular}


Keterangan :

$\begin{array}{llll}\text { Bks } & \text { : Bekasi } & \text { Idr } & \text { : Indramayu } \\ \text { Rkw } & \text { : Karawang } & \text { Crb } & \text { : Cirebon } \\ \text { Sbg } & \text { : Subang } & \text { Kcrb } & \text { : Kota Cirebon }\end{array}$

The radar charts below depict the Z-Score of 27 factors based on the results of typology.

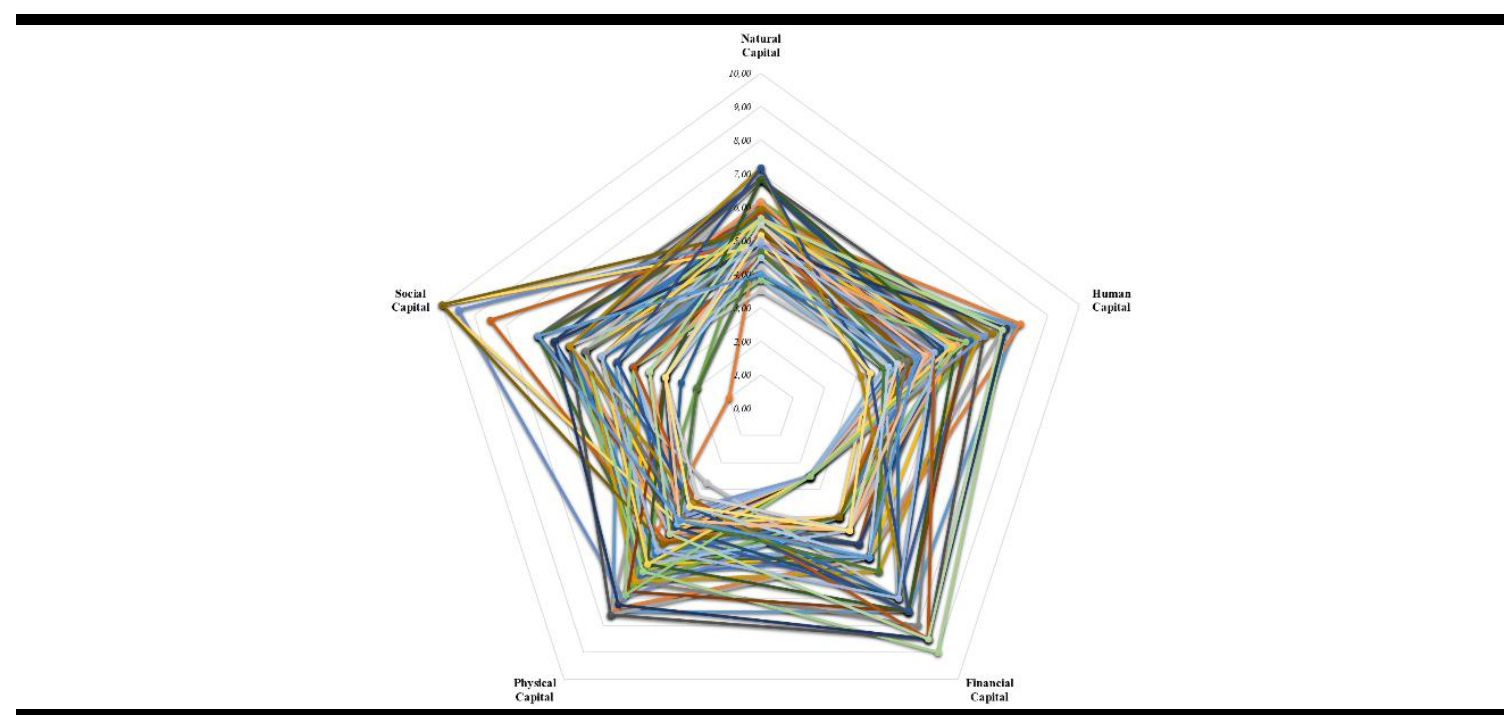

Figure 6. Typology 1; Community Based

For example, Totoran Village, Indramayu Regency, has an agricultural potential of $42.74 \%$ of the total area, but it is dominated by rural communities who earn their living as factory workers (non-agricultural) $82.61 \%$.

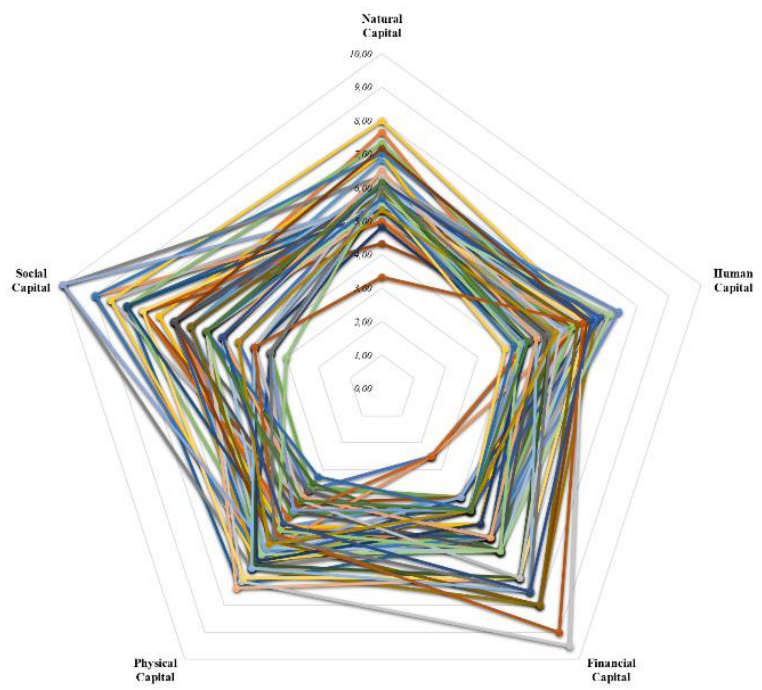

Figure 7. Typology 2; Production Function 
For example, Blanakan Village, Subang Regency, has an agricultural potential of $55.61 \%$, while the dominant community works in the agricultural sector up to $70.03 \%$, and is supported by 15 business groups. Figure. 7 .

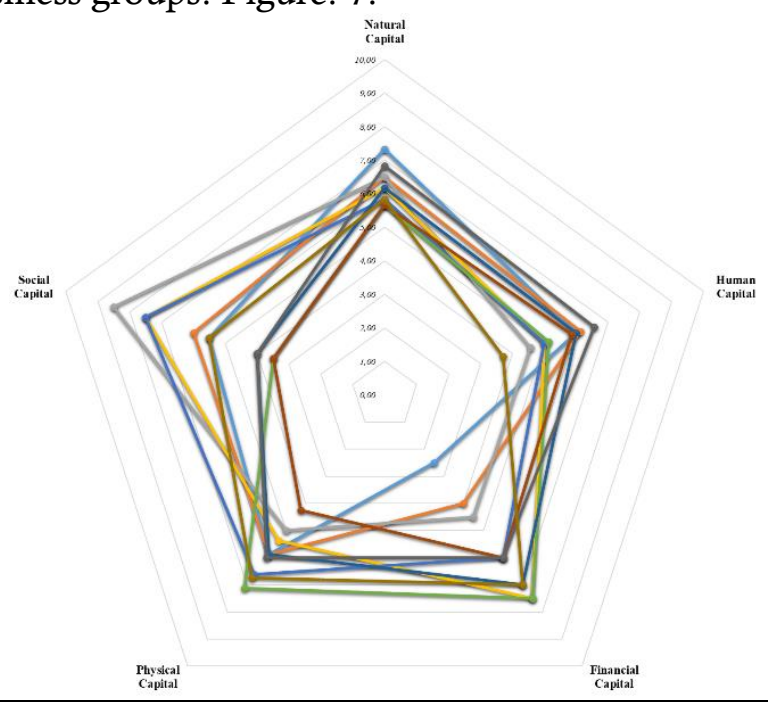

Figure 8. Typology 3; Coastal Ecology Function

For example, Pantaibahagia villages in Bekasi Regency have characteristics of the community that predominantly work in the agricultural sector up to $70.84 \%$ and have extensive mangrove ecosystems, but some have been converted as ponds. Figure. 8.

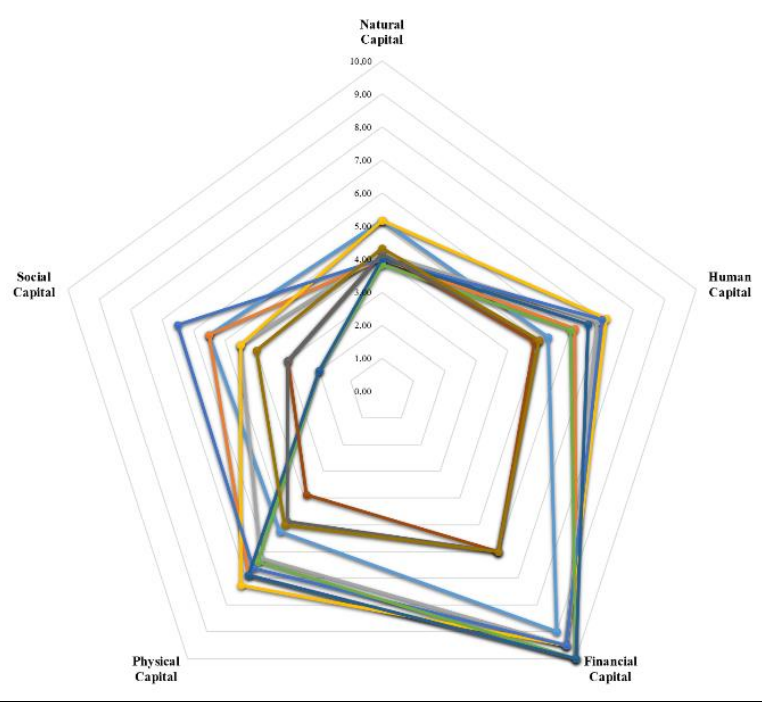

Figure 9. Typology 4 ; City or City expansion tendency

For example, Klayan Village in Cirebon Regency has the characteristics of the population working in the non-agricultural sector of $98.78 \%$, and $40.62 \%$ is dominated by the use of built-in land, as well as high access to banking. Figure. 9. 
Table. 3 Typology Profile Based on the Categorization of Sustainable Livelihoods Approach (SLA)

\begin{tabular}{|c|c|c|c|c|c|}
\hline \multirow[b]{2}{*}{ Typology } & \multicolumn{5}{|c|}{ Dimension (avrg Z-Score) } \\
\hline & $\begin{array}{l}\text { Natural } \\
\text { Capital }\end{array}$ & $\begin{array}{l}\text { Human } \\
\text { Capital }\end{array}$ & $\begin{array}{c}\text { Financial } \\
\text { Capital }\end{array}$ & $\begin{array}{c}\text { Physical } \\
\text { Capital }\end{array}$ & $\begin{array}{l}\text { Social } \\
\text { Capital }\end{array}$ \\
\hline Typology 1 & 5,38 & 5,40 & 5,21 & 5,03 & 4,87 \\
\hline Typology 2 & 5,92 & 5,59 & 5,56 & 5,40 & 5,94 \\
\hline Typology 3 & 6,25 & 5,40 & 5,80 & 5,88 & 5,55 \\
\hline Typology 4 & 4,33 & 6,01 & 8,45 & 5,85 & 3,86 \\
\hline
\end{tabular}

Figures (Figure 6; Figure 7; Figure 8; Figure 9), and tables (Table 3) describe the value of SLA in each rural typology that represents the living conditions of the village which still require encouragement in accordance with the characteristics of natural resources and communities, so it can improve the quality of the community. As the opinion conveyed by (Kamaruddin \& Samsudin, 2014), intensive training and coaching are needed to increase the knowledge and technical skills of the community to ensure the sustainability of resources and the sustainability of their livelihoods. Activities for the initiation of conservation of coastal ecosystems are due to the dependent coastal communities on their existence (Steenbergen \& Holle, 2017). Functional connectivity between villages and cities is important to be addressed by increasing transportation accessibility, especially on the main road network (Bański \& Mazur, 2016), and overcomes the problem of basic infrastructure access, capital ease, and product marketing.

\section{CONCLUSION}

The village is the smallest unit in the Indonesian government administration system, so it is not excessive if the success of solving rural development problems will have a dual impact on the success of development in the wider region. Moreover, rural areas in the north coast of West Java are on the national economic belt lane and it is very likely that a very rapid transition will occur. However, in reality the transition tends to change the characteristics of rural life. The development of the north coast rural areas tends to develop according to business as usual which is in dire need of rapid economic growth, but lacking in environmental management and community capacity building. So that the tendency of rural areas that still have high natural capital but do not have adequate financial facilities and infrastructure is found, and vice versa. The condition of the coastal villages is certainly minimal in the context of the level of quality of services and the level of quality of life of the community.

\section{REFERENCES}

Aji, S., \& Rismana, G. A. (2017). Pemodelan Batas Pengaruh Pusat Pertumbuhan Metropolitan Bodebekkarpur Terhadap Wilayah Belakangnya. 1-12.

Anwar, S. J. (2013). Strategi Nafkah (livelihood) Masyarakat Pesisir Berbasis Modal Sosial. Socius, XIII, 1-21.

Bański, J., \& Mazur, M. (2016). Classification of rural areas in Poland as an instrument of territorial policy. Land Use Policy, 54, 1-17.

Fatmasari, D. (2016). Analisis Sosial Ekonomi dan Budaya Masyarakat Pesisir Desa Waruduwur, Kecamatan Mundu, Kabupaten Cirebon. Al-Amwal, 6, 144-166.

Hamidi, H., Setijonegoro, F. N., Fujitriartanto, Sa'id, A., Harioso, Huda, \& Hardiyanto, A. (2015). Indeks Desa Membangun. Kementerian Desa; Pembangunan Daerah Tertinggal dan Transmigrasi. Jakarta.

Hedlund, M. (2016). Mapping the Socioeconomic Landscape of Rural Sweden: Towards a 
Typology of Rural Areas. Regional Studies, 50, 460-474.

Kamaruddin, R., \& Samsudin, S. (2014). The Sustainable Livelihoods Index: A Tool To Assess The Ability And Preparedness Of The Rural Poor In Receiving Entrepreneurial Project.

Liu, Z., \& Liu, L. (2016). Characteristics and driving factors of rural livelihood transition in the east coastal region of China: A case study of suburban Shanghai. Journal of Rural Studies, 43, 145158.

Natalia, M., \& Alie, M. M. (2014). Kajian Kemiskinan Pesisir di Kota Semarang (Studi Kasus: Kampung Nelayan Tambak Lorok). Jurnal Teknik PWK, III, 50-59.

Prabatmodjo, H. (2006). Wilayah Perdesaan Berkelanjutan: Suatu Eksplorasi Teoritis. Perencanaan Wilayah Dan Kota, 17/No.3, 1-11.

Rugrq, K. D. Q. G. (1991). SRL : Practical concepts for the 21st century. In Ids Discussion Paper (Vol. 296). https://doi.org/ISBN 0903715589

Sajid, A., Ayatullah, Khan, A. N., Iqbal, S., Abbas, S., Natasha Kashif, I. A., ... Salman, M. M. (2017). Socio-Economic Constraints Affecting Sustainable Rural Livelihood. Arts and Social Sciences Journal, 09, 1-5.

Satria, A. (2015). Pengantar Sosiologi Masyarakat Pesisir (p. 162). p. 162. Jakarta: Yayasan Pustaka Obor Indonesia.

Scoones, I. (1998). Sustainable Rural Livelihoods: A Framework for Analysis. IDS Working Paper. https://doi.org/10.1057/palgrave.development.1110037

Serrat, O. (2017). The Sustainable Livelihoods Approach. Knowledge Solutions, 21-26.

Steenbergen, D. J., \& Holle, E. (2017). Effects of rapid livelihood transitions : Examining local co-developed change following a seaweed farming boom. https://doi.org/10.1016/j.marpol.2017.03.026

UNDP. (2017). Application of the Sustainable Livelihoods Framework in Development Projects.

Widodo, S. (2011). Strategi Nafkah Berkelanjutan Bagi Rumah Tangga Miskin Di Daerah Pesisir. Makara, Sosial Humaniora, 15, 10-20. 